\title{
Cómo se genera una investigación científica que luego sea motivo de publicación
}

\author{
Gabriel-Ortega Julio ${ }^{1 *}$
}

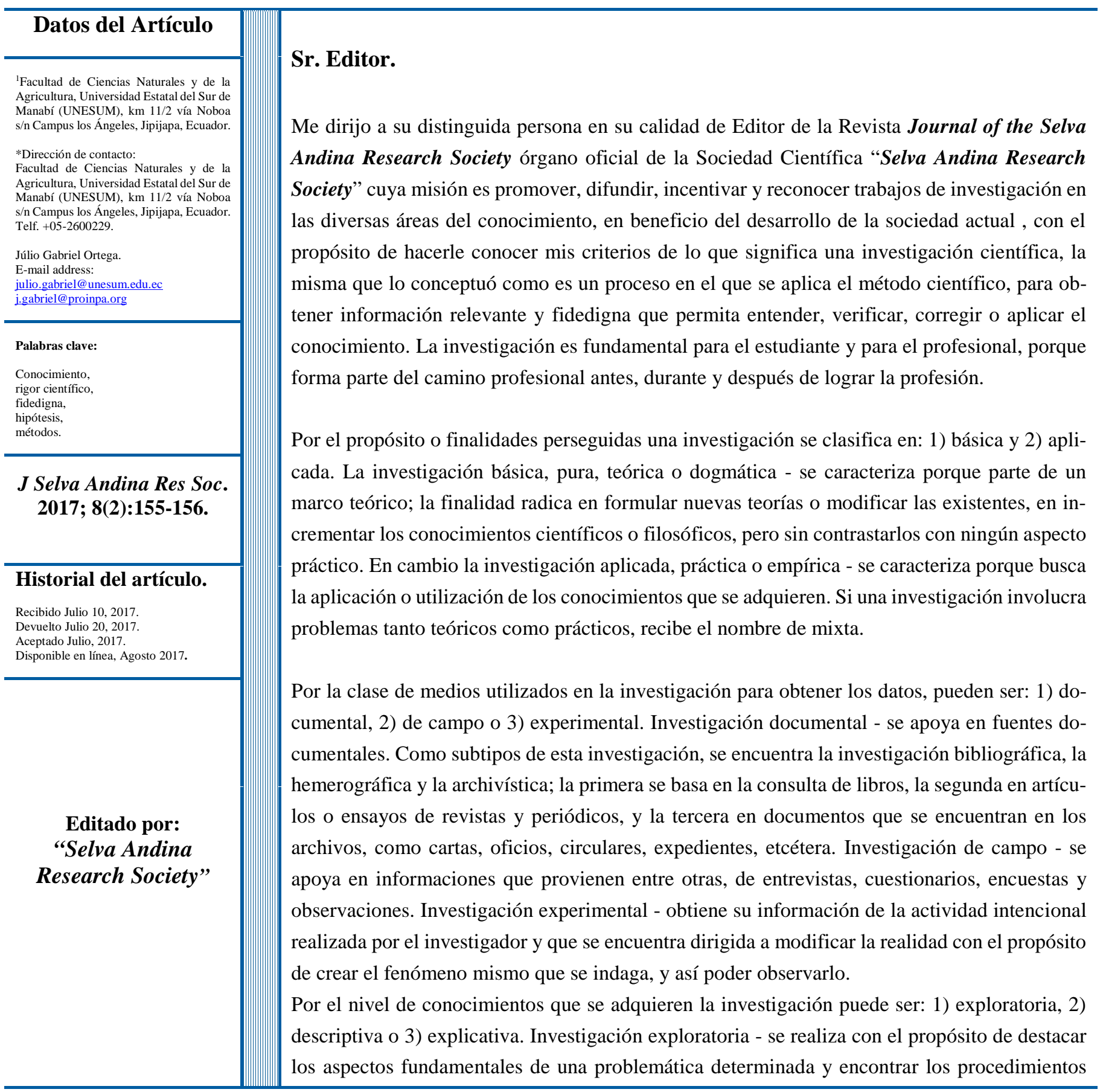


adecuados para elaborar una investigación posterior. Investigación descriptiva - utiliza el método de análisis, se logra caracterizar un objeto de estudio o una situación concreta, señalar sus características y propiedades. Investigación explicativa - requiere la combinación de los métodos analítico y sintético, en conjugación con el deductivo y el inductivo, se trata de responder o dar cuenta de los porqué del objeto que se investiga.

Es fundamental comprender, que los resultados de una investigación pueden o no satisfacer las hipótesis de investigación; sea cual fuere la situación, los resultados deben ser publicados, para que la comunidad científica acceda y tenga una referencia sobre la investigación realizada, con el propósito de comparar y discutir sus propios resultados. En toda investigación, las contribuciones fundamentales son la metodología desarrollada por el o los investigadores, la discusión que generen sobre la base de los resultados encontrados y la literatura existente. Los acápites mencionados son el corazón de la contribución que los investigadores realizan a la comunidad científica, porque esto parte de la aplicación de un proceso riguroso del método científico, que termina en una reflexión profunda sobre el tema. 